\title{
呼気ガス採集法の検討
}

\section{The Effects of Inner Diameter of Respiratory Valve on Pulmonary Ventilation}

\author{
日本体育協会スポーツ科学研究室 \\ Laboratory for Sport Sciences in J.A.S.A. \\ 塚越克已加賀谷熙彦 \\ K. Tsukagoshi H. Kagaya \\ 雨宮輝也黑田善 雄 \\ T. Amemiya Y. Kuroda
}

（受付 昭和 43 年 3 月 1 日)

The effects of the inner diameter of respiratory valve on the pulmonary ventilation and oxygen uptake were studyed.

Five healthy male subjects were asked to run on a treadmill with $8.6 \%$ slope. Each subject equiped a respiratory valve with five kinds of diameter $(19 \mathrm{~mm}, 24 \mathrm{~mm}$, $30 \mathrm{~mm}, 34 \mathrm{~mm}$ and two valves of $19 \mathrm{~mm}$ ) performed all-out running at a given speed at which he could run about 6 minutes. In all experiments, the in ner diameter of the connective tubes in valve, stop cock and bag were $30 \mathrm{~mm}$.

From the experiment, following results were obtained; up to diameter of $30 \mathrm{~mm}$ the larger the diameter of valve, the higher became the pulmonaly ventilation, accompanied with the increasing oxygen uptake. However, a large diameter of 34 $\mathrm{mm}$ did not produce further increase in ventilation. The difference in ventilation between $19 \mathrm{~mm}$ and $30 \mathrm{~mm}$ was found in such an intensive work that demanded over $5011 / \mathrm{min}$. of ventilation and it increased related to the increment of work intensity.

It is concluded that in studying the respiratory function during severe work, it is better to use respiratory valve as large as $30 \mathrm{~mm}$ in diameter.

運動能力あるいは生理的機能を最高度に発揮さ せ，これを数量的に測定することは体育学研究に 欠くことの出来ない研究方法のひとつである。我 々か゚この測定を行なら際に慎重に検討して扔かね ばならないことのひとつに, 測定法あるいは測定 器具が測定すべき能力を十分に発揮させるに足る ものであるか否かということがある。

本研究はエネルギー代謝, 最大酸素摂取量, あ るいは負債量の測定に使用する呼気ガス採集に関 する器具について検討を試みたものである。

\section{I 研究 $の$ 目的}

本研究室は持久性の評価にトレッドミル法を使 用して, 最大換気量, 最大酸素摂取量等の測定を 行っているが, 時として被検者から走行中十分に 呼吸運動, 特に呼気運動が特こな皇ないことを訴 えられる。そしてその理由として, 呼気に際し呼
気众の抵抗を感じることが述べられる。そこで我 々は東京ユニバーシアード夏季大会陸上競技候補 選手の最大酸素摂取量測定の際, 従来の採気用マ スク (呼気口内径 $19 \mathrm{~mm}$ ) として使用されている ものを図 1 に示すよ5に呼気口を 2 口に改造し使 用した。

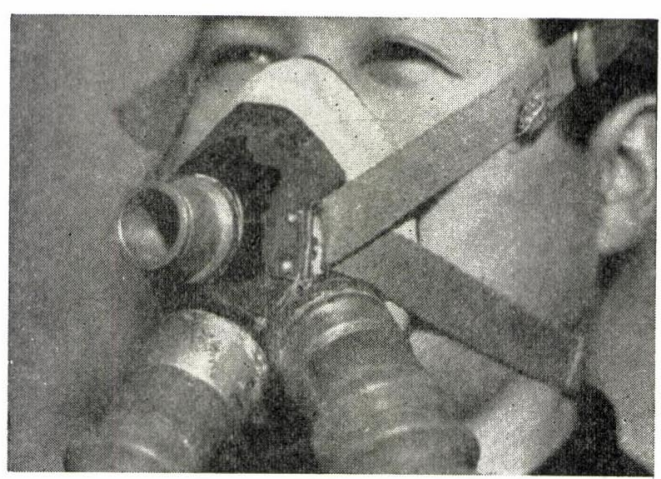

Fig. 1 
Table 1. The effects of inner diameter of respiratory valve on respiratory functions.

\begin{tabular}{|c|c|c|c|c|c|c|c|c|}
\hline \multirow[b]{2}{*}{ Name } & \multirow{2}{*}{$\begin{array}{c}\text { weight } \\
\text { (kg) }\end{array}$} & \multirow{2}{*}{$\begin{array}{l}\text { height } \\
(\mathrm{cm})\end{array}$} & \multicolumn{2}{|c|}{ all-out time } & \multicolumn{2}{|c|}{ Max. $\dot{V}_{E}(\mathrm{BTPS})(l)$} & \multicolumn{2}{|c|}{ Max. $\dot{\operatorname{Vo}} \mathrm{o}_{2}(l)$} \\
\hline & & & $19 \mathrm{~mm}$ & $19 \mathrm{~mm} \times 2$ & $19 \mathrm{~mm}$ & $19 \mathrm{~mm} \times 2$ & $19 \mathrm{~mm}$ & $19 \mathrm{~mm} \times 2$ \\
\hline K. O. & 50.0 & 158.0 & $8.00^{\prime \prime}$ & $9.00^{\prime \prime}$ & 108.63 & 141.98 & 3. 702 & 4.522 \\
\hline K. S. & 60.5 & 166.5 & 8.00 & 8.00 & 137.80 & 161.52 & 4. 604 & 4.879 \\
\hline M. S. & 60.3 & 173. 4 & 4. 00 & 6.03 & 96.78 & 120.92 & 3. 553 & 4.070 \\
\hline J.S. & 51.2 & 170.5 & 8.33 & 7.51 & 107.74 & 127.04 & 3. 827 & 3. 778 \\
\hline T. Y. & 70.0 & 179.5 & 6.00 & 7.00 & 109.05 & 120.78 & 4. 077 & 4.825 \\
\hline
\end{tabular}

Slope of treadmill : $8.6 \%$

Speed : The subject runs at a speed of $240 \mathrm{~m} / \mathrm{min}$. and at the end of 5 minutes the speed increase to $260 \mathrm{~m} / \mathrm{min}$., and at the end of each succeeding minute the speed increase by $20 \mathrm{~m} / \mathrm{min}$. interval.

Subjects : Long distance runner in Japan.

Table 2. Schedule of experiments

1967. 7. $20: 1$ ) Practice of treadmill run.

2) Measurement of cardio-respiratory functions (First trial without respiratory valve).

1967. 7.21 : Measurement of cardio-respiratory function using $19 \mathrm{~mm}$ diameter valve (First trial).

1967. 7.22 : Measurement of cardio-respiratory function using two valves of $19 \mathrm{~mm}$ diameter valve.

1967. 7.23 : Measurement of cardio-respiratory function using $25 \mathrm{~mm}$ diameter valve.

1967. 7. 25 : Measurement of cardio-respiratory function using $34 \mathrm{~mm}$ diameter valve.

1967. $7.26: 1$ ) Measurement of cardio-respiratory function using $30 \mathrm{~mm}$ diameter valve.

2) Measurement of cardio-respiratory function (second trial without valve).

1967. 7.27 : Measurement of cardio-respiratory function using $19 \mathrm{~mm}$ diameter valve (second trial).

Table 3. Meteorological conditions at $12: 00$ in laboratory.

\begin{tabular}{rr|c|c|c}
\hline & room temperature & humidity & $\begin{array}{l}\text { atmospheric } \\
\text { pressure }\end{array}$ & weather \\
\hline 1968. 7.20. & $23.0^{\circ} \mathrm{C}$ & $65.0 \%$ & $758.6 \mathrm{mmHg}$ & fine \\
21. & 25.0 & 66.0 & 759.8 & $\prime \prime$ \\
22. & 21.5 & 63.0 & 757.8 & $\prime \prime$ \\
25. & 22.2 & 70.0 & 754.9 & $\prime \prime$ \\
26. & 23.5 & 63.0 & 754.3 & $\prime \prime$ \\
27. & 23.6 & 72.0 & 754.2 & $\prime \prime$ \\
\hline
\end{tabular}

そして従来のマスクと改造マスクによるそれぞ れの測定値を比較した結果，表 1 に示すよ5に， 2 ロマスク使用時の走行中最大換気量は 10〜20l の增加を示し，また酸素摄取量，持久走時間も增 大した。

この結果から，従来使用してきた採気マスク呼 気口は換気量が多量に增大寸るよ5な作業中の呼 気ガスを採用するのに小さすぎるのではないかと 考えられた。われわれは呼気口の大きさと，作業 中換気量との関係を明らかにする目的で以下に述
ベる研究をおこなった。

\section{II 実 験 方 法}

実験は表 2 に示すよ 5 に昭和 42 年 7 月 20 日よ り，表 3 に示寸気象条件のもとに日本体育協会ス ポーツ科学研究室で扰こなった。

被検者は表 4 に示すよ5に 5 名でいずれる大学 陸上競技部に所属する健康な青年男子である。

実験では被検者の換気量を最高に增大させる3 ために，作業負荷として年り 5 度の傾斜をもつト 
Table 4. Anthropometric and some other characterizing data of subjects. All subjects belong to athletic club of Tokyo Gakugei Univ.

\begin{tabular}{l|c|c|c|c|c|c}
\hline \multicolumn{1}{c|}{ Name } & age & birth date & $\begin{array}{c}\text { weight } \\
(\mathrm{kg})\end{array}$ & $\begin{array}{c}\text { height } \\
(\mathrm{cm})\end{array}$ & \multicolumn{1}{|c}{ events } & $\begin{array}{c}\text { experience } \\
\text { years }\end{array}$ \\
\hline M. Asakura & 21 & 1945.9 .16 & 53.6 & 168.0 & long distance & 10.0 \\
I. Shiraishi & 20 & 1946.10 .4 & 60.2 & 166.5 & middle distance & 5.0 \\
K. Nagami & 20 & 1946.12 .4 & 63.0 & 170.0 & javelin throw & 3.5 \\
K. Nukui & 22 & 1945.4 .15 & 65.4 & 168.0 & long distance & 9.0 \\
S. Aoki & 21 & 1946.10 .3 & 70.0 & 175.8 & sprint & 9.3 \\
\hline
\end{tabular}

レッドミル上のオールアウト走を用いた。各被検 者の走行速度は表 5 に示した。

この走行速度は各被検者の呼吸・循環機能が十 分に発揮されるのに必要な時間2) だけ作業を持続 できるよ5に選定されたものである。

我々は実験に先きだち, 呼気口内径 $24 \mathrm{~mm}, 30$ $\mathrm{mm}, 34 \mathrm{~mm}$ の 3 種の採気用マスクを製作した。 これら 3 種のマスクとさきに製作した呼気口 2 口 のマスク，従来使用してきたマスク（呼気口 19 $\mathrm{mm}$ ）を装置した場合および採気マスクを装着し ない場合の合計 6 通りにつき，上記の作業負荷を それぞれの被験者に課し，次に述べる項目の測定 をおこなった。なお採気マスクのデッドスペース はいずれる約 $200 \mathrm{ml}$ である。

1. 心拍数：胸部双極誘導の心電図によった。

2. 呼吸数 : サーミスター法による呼吸曲線か らもとめた。

記録器は三栄測器製ユニパーサルレコーダーを 使用し、ペーパースピード $1.5 \mathrm{~cm} / \mathrm{sec}$ の条件によ り記録した。なお心拍数は運動初期ならびに回復 初期は 30 秒ごと, 運動中ならびに回復後期は 1 分ご， 12 秒間の心電図 $\mathrm{R}$ 棘をかぞえ 1 分間当 りの值に換算した。呼吸についても同様にかぞえ 1 分間当りに換算した。

3. 走行中換気量, 最大換気量

4. 走行中酸素摂取率, 酸素拄取量, 最大酸素 摄取量

5. 走行中炭酸ガス排出\%，炭酸ガス排出量， 最大炭酸ガス排出量

3〜5 について呼気はダグラスバックに集め, 労研式大型ガス分析器によって分析測定した。な お走行中の呼気ガスの採取は 1 分間隔で行い, 走 行終了時の採気時間が，40秒に満たないものは 切り唅てた。
本研究は採気マスクの呼気口径を中心に検討を 進めたものであるが，採気マスクの外に十分な換 気をさまたげる原因として接続管，三方コック， ダグラスバックならびにそのコックが関係してい るすのと考えられる。

我々は採気用マスクの検討に先立ち，まずこれ ら接続管, コック類について検討を加え，これら 器具は被検者の換気能力を十分に発揮させること のできるものを使用し，マスク呼気口の口径にの み相違があるだけにして，本実験をすすめること にした。そのために次のような予備実験をおこな った。すなわち，一般に呼吸機能の測定に用いて いる 13.5l-Benedict-Roth 型レスピロメーター を使用し，接続管の口径と最大換気量との関係を みた。

レスピロメーターの接続管をはずし，一方をと じ, 長さはいずれる $1 \mathrm{~m} て ゙$ 内径がそれぞれ $10 \mathrm{~mm}$, $14 \mathrm{~mm}, 18 \mathrm{~mm}, 25 \mathrm{~mm}, 32 \mathrm{~mm}$ の接続管をつけて 最大換気量を測定した。なお同じ内径の呼気口 （弁なし）を持つ採気 マスクを使用した。測定結 果は図 3 に示す通りである。

接続管の内径 $25 \mathrm{~mm}$ までは, 内径が増すに従 い順次 MBC は增加するが，内径 $25 \mathrm{~mm}, 32 \mathrm{~mm}$ 及び従来使用しているレスピロメーターによる MBC はほとんど等しいことがわかった。

したがって接続管の内径は $25 \mathrm{~mm}$ あれば $\mathrm{MBC}$ 約 $200 l$ の能力を持つものでもその 能力を十分に 発揮できるものと考えられる。しかし我々は安全 性を加味して, 本実験に用いる接続管の内径は 30 $\mathrm{mm}$ とした。

たたし従来のマスクを使用する実験の際は従来 通り, 接続管の内径 $20 \mathrm{~mm}$, コック内径 $20 \mathrm{~mm}$ の ものを使用することにした。

また従来本研究室で連続採気に使用している切 


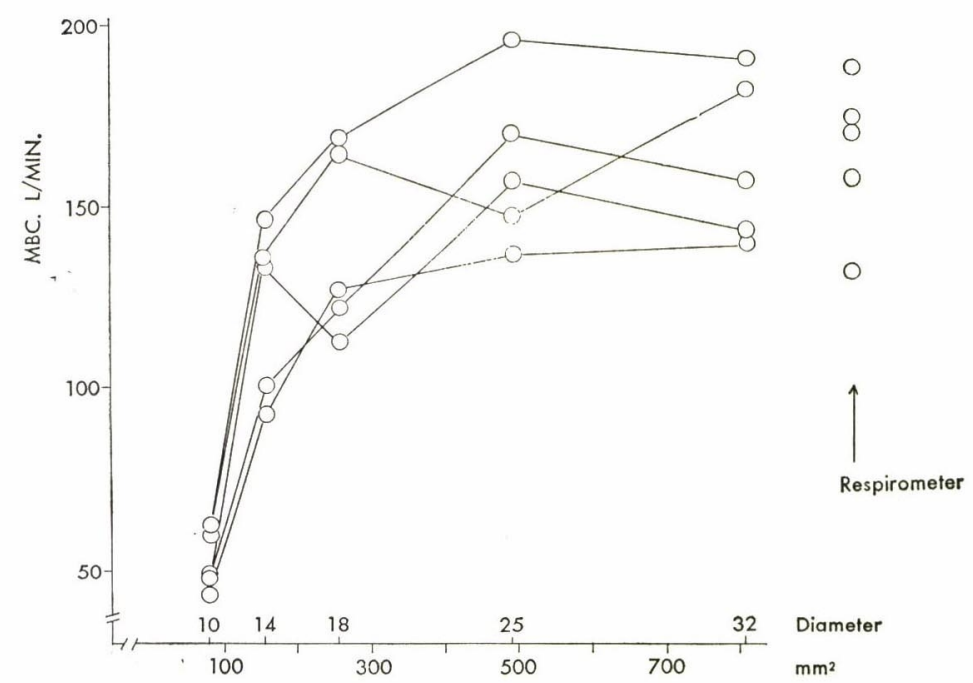

Fig. 3 Relation between MBC. and Diameter of Connective Tube

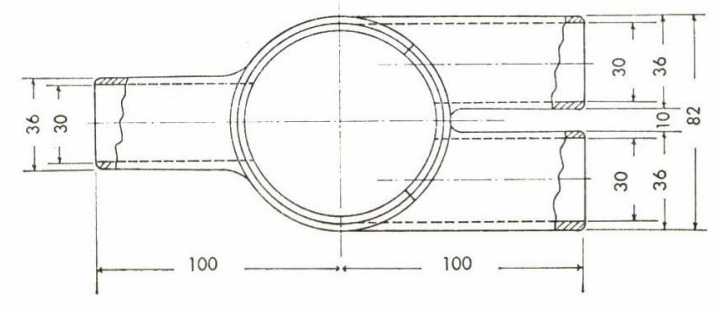

Fig. 2-1

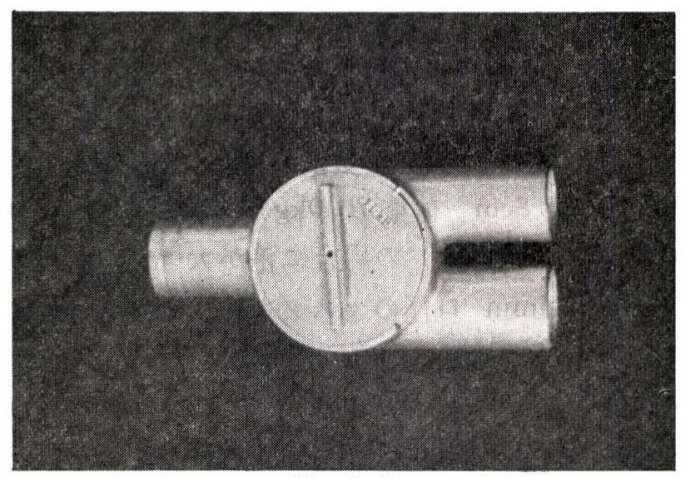

Fig. 2-2
換用三方コックは， $\mathrm{T}$ 字型に設計されたものであ り，直角方向に切換觉ることは呼気抵抗を增加さ せる一因でもあるため図 2 に示すよ5 設計した 三方コックを製作した。コックの内径は先に決め た接続管の内径と合せ $30 \mathrm{~mm}$ とした。

またダグラスバッグについては換気量が増大し ても余裕を持って採集出来るよ 5 に, $200 l$ の容量 を持つものを使用し，バックのコッグは従来と同 一の機構を持ち内径 $30 \mathrm{~mm}$ のものを製作した。

\section{III 結果}

\section{1. オールアウト走時間}

各マスクを用いたときのそれぞれのトレッドミ ルオールアウト走時間を表 5 にしめした。被検者 永見は $19 \mathrm{~mm}$ 口径のマスクを使用したときに比 較的よい成績をしめしたが，他の被検者はいずれ も口径の大きいマスクを使用したときに持久走時 間がながかった。マスクを装着しない場合と19 $\mathrm{mm}$ 口径のマスクを使用した場合の測定は 2 回行 なった。これは 1 回目の測定で被験者が測定に不 なれのため能力を十分に発揮できないのではない かといらことを考慮して，2 回目の測定を括こな ったからである。以下にのべる結果は, いずれも 2 回目の測定值である。 
Table 5. Relation between Diameter of Resp. Valve and All-out running time

\begin{tabular}{c|c|c|c|c|c}
\hline \multicolumn{1}{c|}{} & Asakura & Shiraishi & Nagami & Nukuı & Aoki \\
\hline Diameter & $* 3^{\prime} 21^{\prime \prime}$ & $* 3^{\prime} 28^{\prime \prime}$ & $5^{\prime} 00^{\prime \prime}$ & $5^{\prime} 00^{\prime \prime}$ & $4^{\prime} 42^{\prime \prime}$ \\
tree (1) & 730 & 532 & 600 & 408 & 623 \\
free (2) & - & - & 400 & 338 & 431 \\
$19 \mathrm{~mm}(1)$ & 530 & 540 & 544 & 405 & 550 \\
$19 \mathrm{~mm}(2)$ & 715 & 558 & 443 & 431 & 530 \\
$19 \mathrm{~mm} \times 2$ & 700 & 615 & 630 & 445 & 62 \\
$24 \mathrm{~mm}$ & 813 & 602 & 512 & 430 & 600 \\
$30 \mathrm{~mm}$ & 802 & 702 & 540 & 438 & 612 \\
$34 \mathrm{~mm}$ & $5^{\circ}$ & $5^{\circ}$ & $5^{\circ}$ & $5^{\circ}$ & $5^{\circ}$ \\
slope & $220 \mathrm{~m} / \mathrm{min}$. & $220 \mathrm{~m} / \mathrm{min}$. & $200 \mathrm{~m} / \mathrm{min}$. & $240 \mathrm{~m} / \mathrm{min}$. & $200 \mathrm{~m} / \mathrm{min}$. \\
\hline
\end{tabular}

* speed : $240 \mathrm{~m} / \mathrm{min}$.
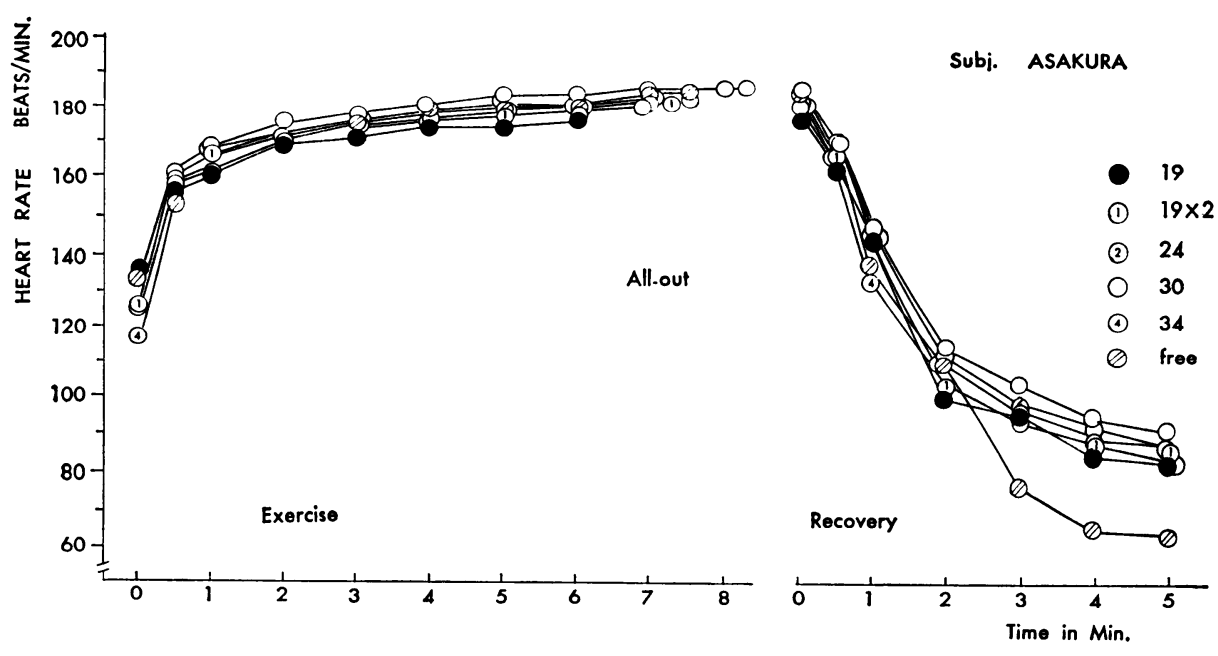

Fig. 4 Changes of Heart Rate

\section{2. 心拍数变動}

図 4 に走行中の心拍数変動の 1 例をしめし, 表 6 に 5 名の被検者のオールフウト時の心拍数をl. めした。図4の例では，走行中心拍数はいずれの 口径の場合もほほ同様の経過をたどって増加し， 最大値をしめしてオールアウトにいたっている。 $19 \mathrm{~mm}$ 口径の時に走行中, オールアウト時ともに 心拍数がやや低いが, 表 6 にみられるよ 5 に他の 被験者では, オールアウト時心拍数とマスクロ径 の大きさとは関係が認められない。

\section{3. 呼吸数变動}

図 5 に呼吸数変動の一例をしめした。この例で は, $19 \mathrm{~mm}$ 口径のマスクを使用したときは呼吸数
は走行中, オールアウト時ともに低い。各被検者 のオールアウト時呼吸数を表 7 にめしたが, 全 被検者とも19mm 口径のマスクを使用したとき の呼吸数が低い。

特に体格の大きく換気量の大きい被検者青木 （身長 $175.8 \mathrm{~cm}$. 体重 $70.0 \mathrm{~kg}$ )，貫井(身長 168.0 cm. 体重 $65.4 \mathrm{~kg}$ ）の場合に差が大きい。貫井が $30 \mathrm{~mm} 24 \mathrm{~mm}$ 口径のマスクを使用したときの才 ールアウト時呼吸数は毎分 100 回とい5值を示し めたのにたいし，19mm 口径のときは毎分 65 回 にとどまっている。この被検者貫井のオールアウ ト時の心電図, 呼吸曲線の記録を図6にしめし た。 
Table 6. Relation between diameter of Resp. valve and maximal values for heart rate at all-uut.

\begin{tabular}{|c|c|c|c|c|c|}
\hline $\begin{array}{l}\text { Diameter } \\
\text { Subj. }\end{array}$ & Asakura & Shiraishi & Nagami & Nukuı & Aokı \\
\hline free (1) & - & - & 188 & 180 & 193 \\
\hline free (2) & 184 & 191 & 183 & 178 & 190 \\
\hline $19 \mathrm{~mm}$ (1) & - & - & 177 & 180 & 180 \\
\hline $19 \mathrm{~mm}$ (2) & 176 & 193 & 184 & 176 & 190 \\
\hline $19 \mathrm{~mm} \times 2$ & 181 & 192 & 182 & 175 & 188 \\
\hline $24 \mathrm{~mm}$ & 183 & 188 & 182 & 178 & 187 \\
\hline $30 \mathrm{~mm}$ & 186 & 191 & 180 & 186 & 183 \\
\hline $34 \mathrm{~mm}$ & 181 & 191 & 182 & 177 & 185 \\
\hline
\end{tabular}

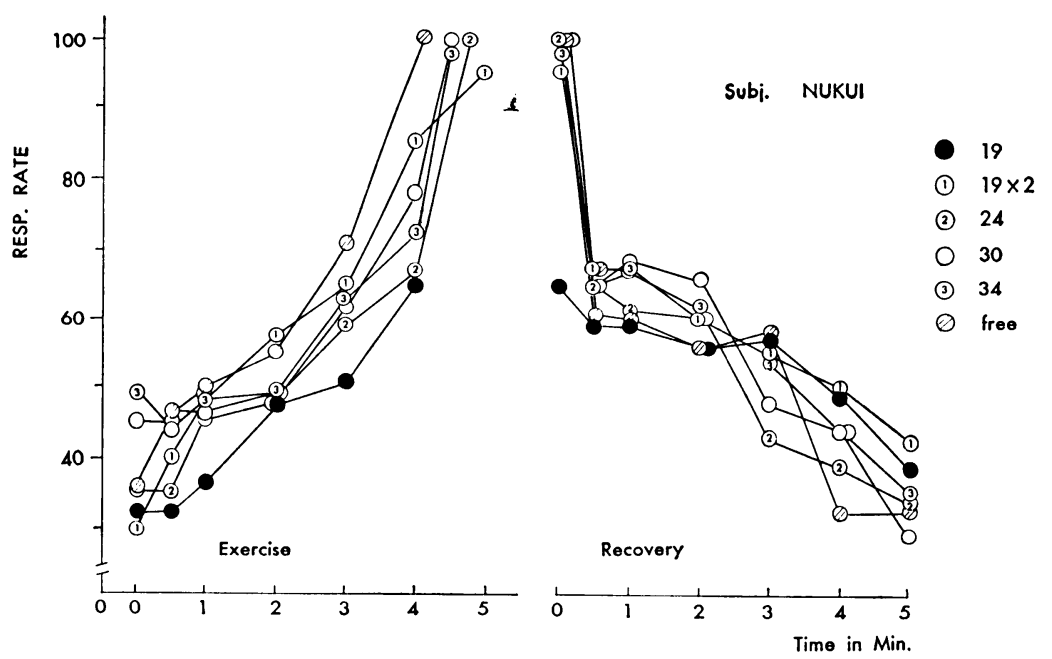

Fig. 5 Relation between Changes of Resp. Rate and Diameter of Resp. Valve

Table 7. Relation between diameter of Resp. valve and maximal values for respiratory rate at all-aut.

\begin{tabular}{|c|c|c|c|c|c|}
\hline Diameter & Asakura & Shiraishi & Nagami & Nukui & Aoki \\
\hline free (1) & - & - & 72 & 100 & 73 \\
\hline free (2) & 64 & 75 & 74 & 100 & 73 \\
\hline $19 \mathrm{~mm}$ (1) & - & - & 53 & 65 & 55 \\
\hline $19 \mathrm{~mm}$ (2) & 59 & 63 & 56 & 65 & 56 \\
\hline $19 \mathrm{~mm} \times 2$ & 62 & 73 & 63 & 95 & 65 \\
\hline $24 \mathrm{~mm}$ & 61 & 71 & 60 & 100 & 71 \\
\hline $30 \mathrm{~mm}$ & 63 & 75 & 57 & 100 & 67 \\
\hline $34 \mathrm{~mm}$ & 63 & 72 & 57 & 98 & 67 \\
\hline
\end{tabular}

\section{4. 換気量}

図7-1，2 に走行中換気量の変動をしめした。 走行開始初期の換気量の各マスク間の差異は比較 的少ないが，時間の経過にしたがって $19 \mathrm{~mm}$ 口 径のマスク使用時の換気量は他のマスク使用時の
換気量に比して增加が少ない。すなわち，換気量 が増大するにしたがい，従来のマスクでは十分な 換気がおこなわれていないことをしめしている。 各マスクと走行中最大換気量との関係を表 8 , 図 8 にしめした。従来のマスク使用時の最大換気 

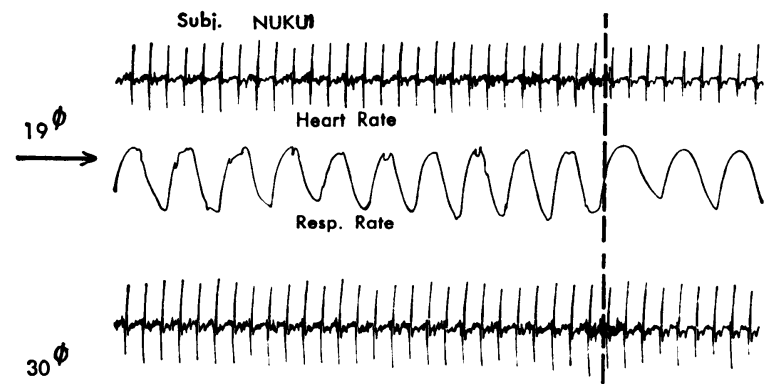
$30^{\phi}$ curculourun

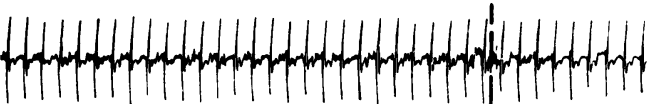
FREE

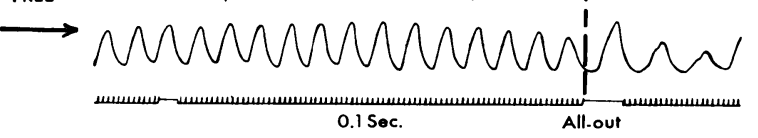

Fif. 6 Relation between ()'ametr, of Resp. Valve and Heart Rate and Resp. Rate
量が 103-127l/分 (BTPS) の值であるのに たいし，24mm のマスク 使用時には 130$164 l /$ 分(BTPS), 30mm のマスク使用時で は 133-171l/分(BTPS) に增大する。呼気 口の口径をさらに大きく $34 \mathrm{~mm}$ にしたと きの值は $129-167 / /$ 分で $30 \mathrm{~mm}$ の口径に 比してとくに增大をしめしていない。

13. $5 l$-Benedict-Roth 型レスピロメータ 一で測定した MBC と各マスクの走行中 換気量との比率を図 9 にしめした。

$19 \mathrm{~mm}$ 口径のマスクでは各被㭘者の MBC のおよそ60\%の換気量を走行中に 発揮しているのにたいし， $30 \mathrm{~mm}$ 口径マス クでは拉よそ $80 \%$ に增大している。

\section{5. 酸素摄取率}

図10にみられるよ5に, 走行中酸素摂取 率は，次第に低下してオールアウト状態に

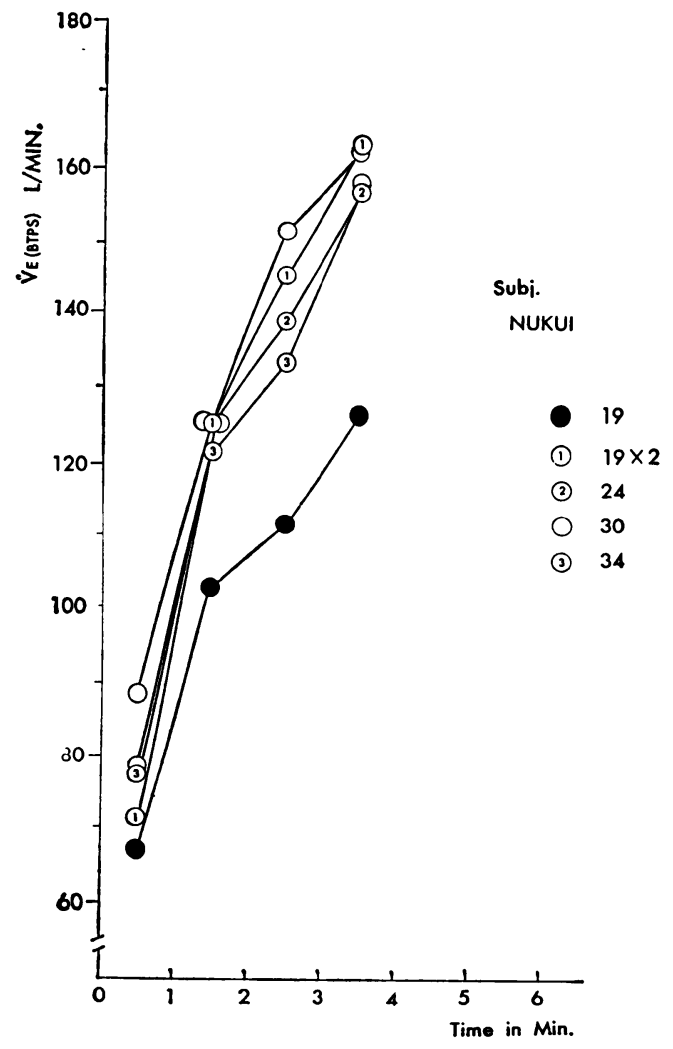

Fig. 7-1 Changes of Pulmonary Ventilation

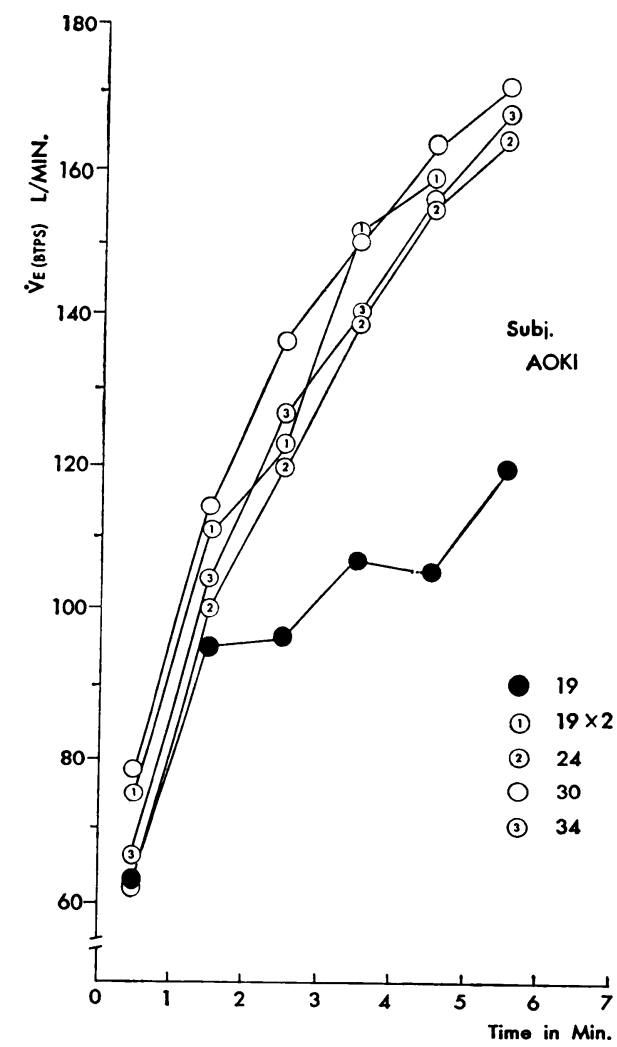

Fig. 7-2 Changes of Pulmonary Ventilation 
Table 8. Relation between diameter of Resp. valve and maximal values for Pulmonary ventilation in running.

\begin{tabular}{|c|c|c|c|c|c|c|}
\hline $\begin{array}{l}\text { Subj. } \\
\text { Diameter }\end{array}$ & & Asakura & Shiraishı & Nagami & Nukui & Aoki \\
\hline \multirow{2}{*}{$\begin{array}{l}19 \mathrm{~mm} \\
\text { (1st test) }\end{array}$} & $\mathrm{S}$ & - & - & 92.42 & 97.35 & 92.87 \\
\hline & B & - & - & 112.20 & 136.45 & 112.56 \\
\hline \multirow{2}{*}{$\begin{array}{l}19 \mathrm{~mm} \\
(2 \mathrm{nd} \text { test })\end{array}$} & $\mathrm{S}$ & 86.90 & 100.76 & 84.39 & 103. 66 & 87.56 \\
\hline & B & 106. 10 & 123.03 & 103. 04 & 126.57 & 119.81 \\
\hline \multirow{2}{*}{$19 \mathrm{~mm} \times 2$} & $\mathrm{~S}$ & 118.46 & 122.51 & 106.09 & 135.00 & 131.51 \\
\hline & B & 143.33 & 153.60 & 128.37 & 163. 35 & 159. 39 \\
\hline \multirow{2}{*}{$24 \mathrm{~mm}$} & $\mathrm{~S}$ & 123.80 & 129.14 & 106.82 & 129. 12 & 135.41 \\
\hline & B & 150. 91 & 157.42 & 129. 68 & 156.75 & 164.39 \\
\hline \multirow{2}{*}{$30 \mathrm{~mm}$} & $\mathrm{~S}$ & 120.99 & 134.86 & 108.94 & 134.67 & 140.28 \\
\hline & B & 147.73 & 164.66 & 133.02 & 161.60 & 171.28 \\
\hline \multirow{2}{*}{$34 \mathrm{~mm}$} & $\mathrm{~S}$ & 117.44 & 132.13 & 107.03 & 130. 62 & 138. 30 \\
\hline & B & 142.57 & 160.14 & 129.72 & 158. 31 & 167.62 \\
\hline
\end{tabular}

S : STPD B : BTPS

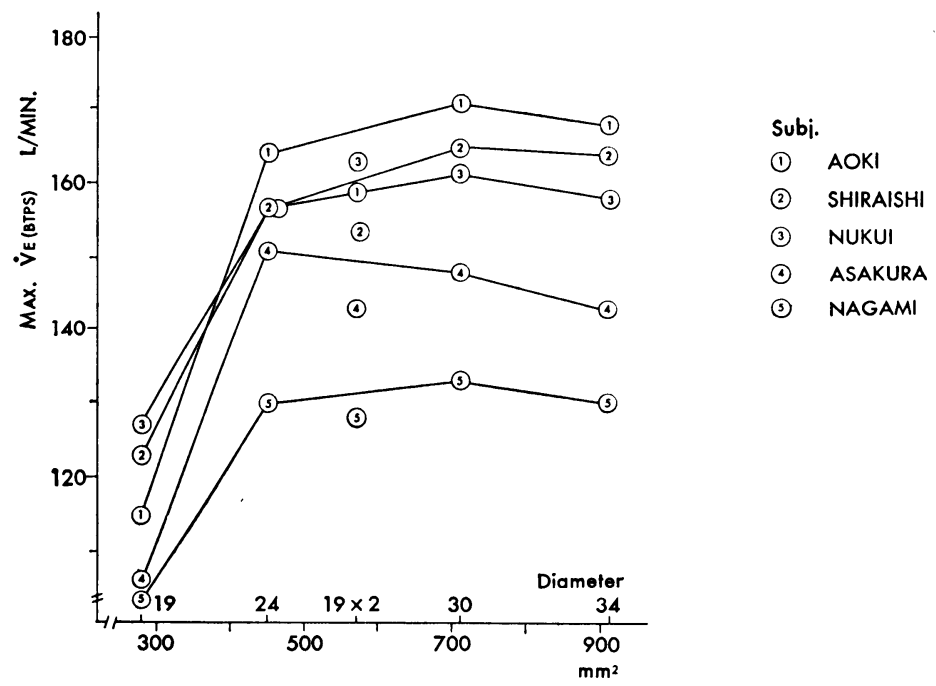

Fig. 8 Belation between $\dot{V}$. and Diameter of Respiratory Valve

達するが，この例での大きな特徵は，19mm 口径 のマスクを使用したとき，摂取率は走行中比較的 高い水準を保ち、オールアウト時にも他のマスク 使用時より高い値をしめしていることである。 他の被検者では $19 \mathrm{~mm}$ 口径のとき走行中摂取 率は必らずしも高い水準を保つとは限らないか：
表 10 にみられるようにオールアウト時掑取率は 各被検者共通に高い值をしめしている。

\section{6. 酸素摄取量}

酸素掑取量が採父マスク呼気口の口径によって 影響をうけるか否かは重要な問題である。図 11 に走行中酸素摄取量の変動の 1 例をしめした。困 
Table 9. Relation between MBCे, diameter of Resp. valve and maximal values for Pulmonary ventilation.

\begin{tabular}{|c|c|c|c|c|c|c|}
\hline \multicolumn{2}{|r|}{ Subject } & Asakura & Shiraishi & Nagami & Nukui & Aoki \\
\hline \multicolumn{2}{|r|}{$\mathrm{MBC}(\bar{l})$} & 156.7 & 167.2 & 147.5 & 179.5 & 198. 3 \\
\hline \multirow{6}{*}{ 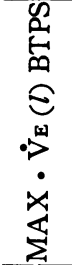 } & $19 \mathrm{~mm}$ (1) & - & - & 112.20 & 136.45 & 112.56 \\
\hline & $19 \mathrm{~mm}$ (2) & 106. 10 & 123.03 & 103.04 & 126.57 & 119.81 \\
\hline & $19 \mathrm{~mm} \times 2$ & 143. 33 & 153. 60 & 128.37 & 163.35 & 159. 39 \\
\hline & $24 \mathrm{~mm}$ & 150.91 & 157.42 & 129. 68 & 156.75 & 164. 39 \\
\hline & $30 \mathrm{~mm}$ & 147.73 & 164.66 & 133.02 & 161.60 & 171.28 \\
\hline & $34 \mathrm{~mm}$ & 142.57 & 160.14 & 129.72 & 158. 31 & 167.62 \\
\hline
\end{tabular}

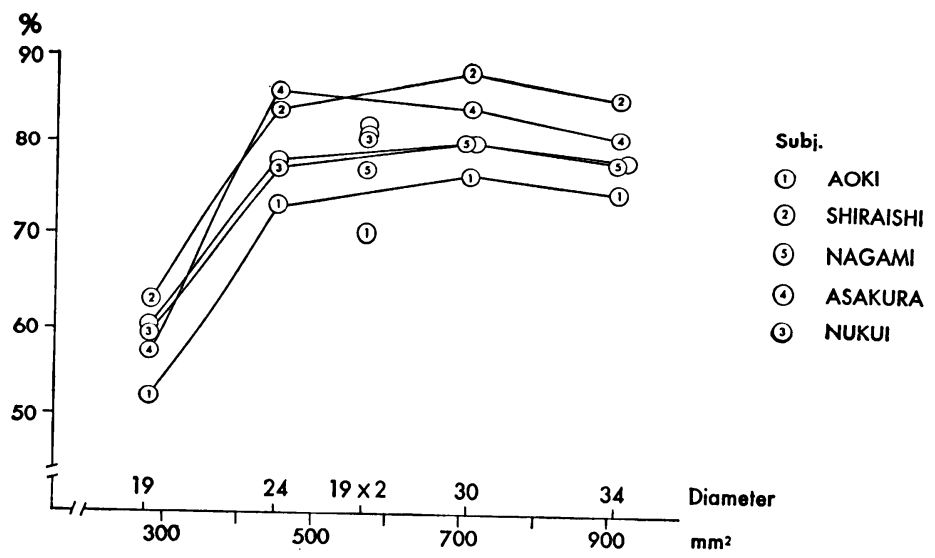

Fig. 9 Relation between Max. $\dot{V}_{\mathrm{E} .} / \mathrm{MBC} \times 100$ and Diameter of Resp. Valve

Table 10. Relation between diameter of Resp. valve and Oxygen removal at all-out.

\begin{tabular}{|c|c|c|c|c|c|}
\hline Diameter & Asakura & Shiraishi & Nagami & Nukui & Aoki \\
\hline $19 \mathrm{~mm}$ (2) & 37.2 & 40.9 & 44.4 & 40.3 & 41.8 \\
\hline $19 \mathrm{~mm} \times 2$ & 30.2 & 29.1 & 35.2 & 31.0 & 31.5 \\
\hline $24 \mathrm{~mm}$ & 31.6 & 31.5 & 36.4 & 37.0 & 32.9 \\
\hline $30 \mathrm{~mm}$ & 32.3 & 32.5 & 36.2 & 34.7 & 35.6 \\
\hline $34 \mathrm{~mm}$ & 33.6 & 32.2 & 36.4 & 32.8 & 33.9 \\
\hline
\end{tabular}

の例では, $19 \mathrm{~mm}$ 口径のとき走行開始から 3 分経 過まで酸素摄取量は必らずしも低い值といえな い。しかし他の口径のマスク使用時に摄取量が 3 分経過後も同一水準を保つか, あるいは増加をつ つけるのにたいし，19mm 口径のマスクの際は， 3 分をこえてからむしろ減少してオールアウトに なっている。

各被検者の最大酸素摄取量とマスク呼気口の口
径との関係を表11，図12 としめした。

両者の関係は換気量の場合と同様で，19mm 口 径のときは走行中酸素摄取量の最大值が $3.7 \sim 4.2$ l/分であるのにたいし, $30 \mathrm{~mm}$ 口径では 4.2〜5.0 l/分の值をしめしている。

\section{7. 岸酸カス排出量}

走行中炭酸ガス排出\%は図 13 にしめす例と同 様に各被検者とも $19 \mathrm{~mm}$ 口径のマスク使用時に 


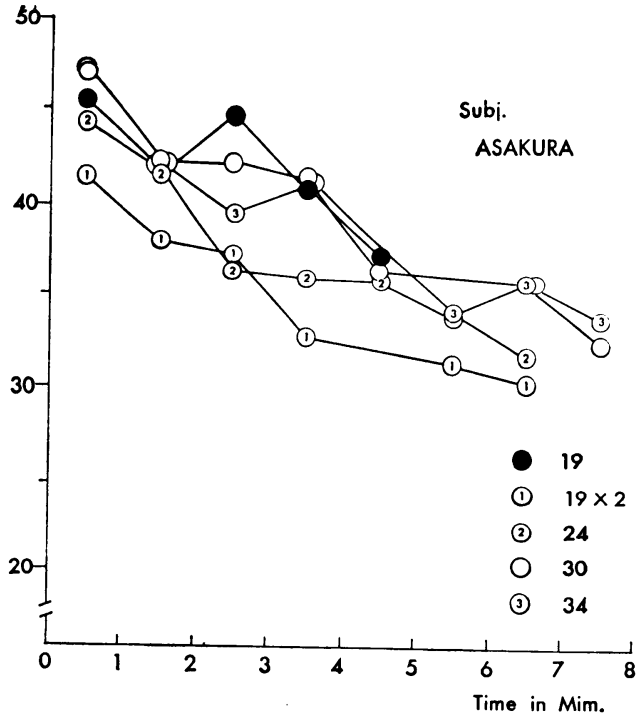

Fig. 10 Changes of $\mathrm{O}_{2}$ Removal

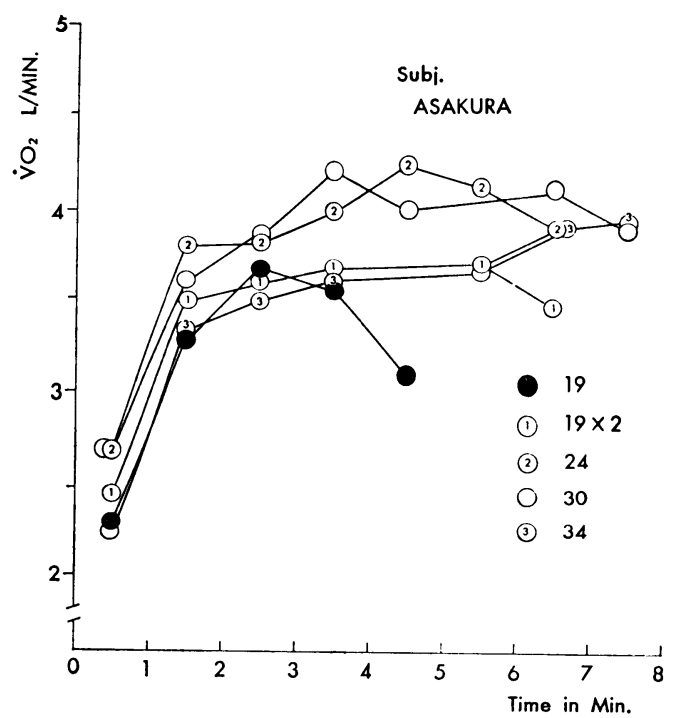

Fig. 11 Changes of $\mathrm{O}_{2}$ Uptake

Table 11. Relation between diameter of Resp. valve and maximal values for oxygen uptake $(l / \mathrm{min})$.

\begin{tabular}{c|c|c|c|c|c}
\hline \multicolumn{1}{c|}{ Subj. } & Asakura & Shiraishi & Nagami & Nukui & Aoki \\
\hline Diameter & - & - & 3.870 & 4.379 & 3.836 \\
$19 \mathrm{~mm}(1)$ & 3.672 & 4.058 & 4.009 & 4.177 & 4.026 \\
$19 \mathrm{~mm}$ (2) & 3.708 & 3.834 & 3.957 & 4.308 & 4.721 \\
$19 \mathrm{~mm} \times 2$ & 4.245 & 4.084 & 4.029 & 4.777 & 4.754 \\
$24 \mathrm{~mm}$ & 4.213 & 4.281 & 3.960 & 4.921 & 4.994 \\
$30 \mathrm{~mm}$ & 3.946 & 4.273 & 3.942 & 4.510 & 4.688 \\
$34 \mathrm{~mm}$ & & & & \\
\hline
\end{tabular}

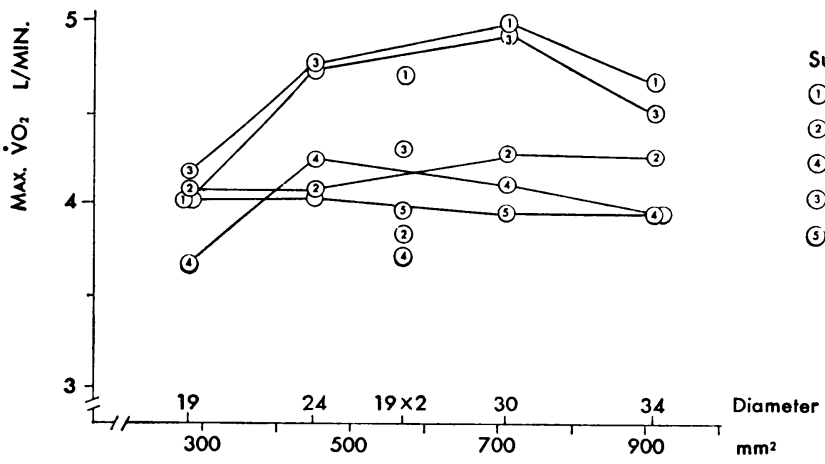

Fig. 12 Relation between Max. $\dot{V} o_{2}$ and Diameter of Resp. Valve 


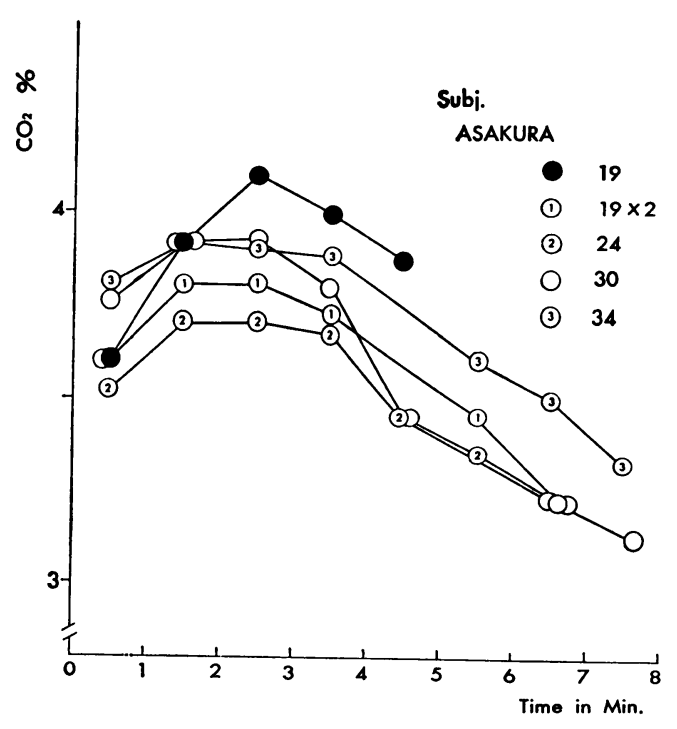

Fig 13 Changes of $\mathrm{CO}_{2} \%$

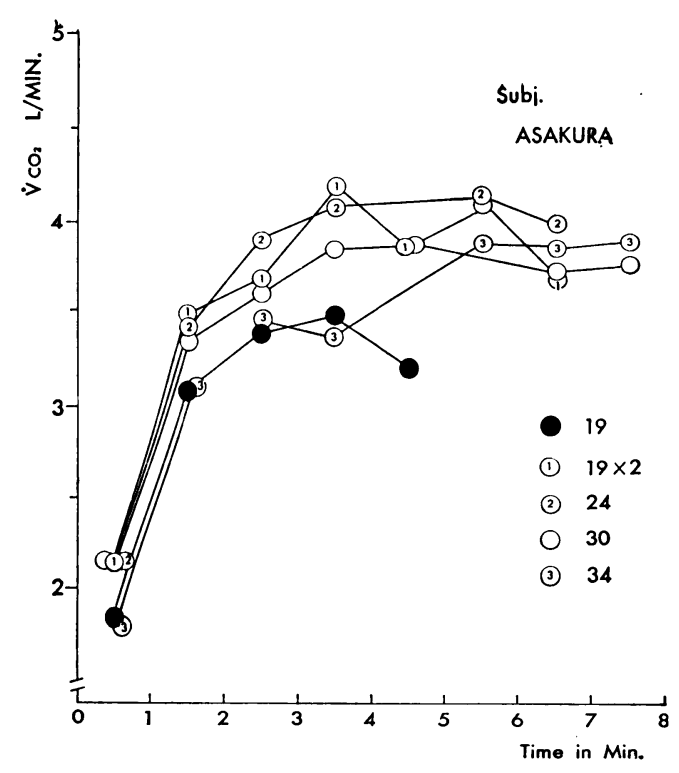

Fig. 14 Changes of $\dot{\mathrm{Co}}_{2}$

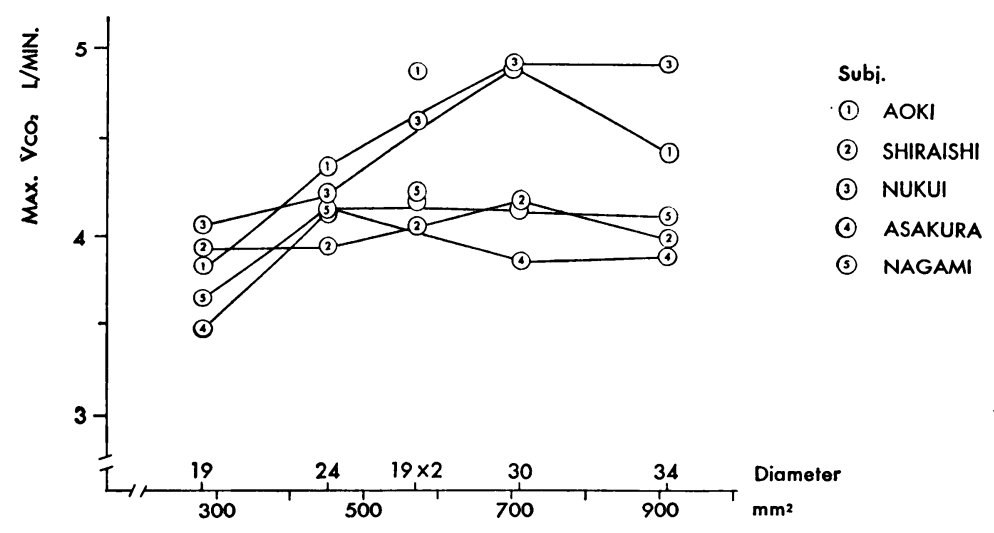

Fig. 15 Relation between Max. $\dot{\mathrm{V}} \mathrm{CO}_{2}$ and Diameter of Resp. Valve

大きな值をしめした。しかしながら図 14 で走行 中炭酸ガス排出量の変動をみると $19 \mathrm{~mm}$ 口径の とき低い値をしめし, 図 15 の走行中最大炭酸ガ ス排出量と呼気口の関係をみても呼気口 $19 \mathrm{~mm}$ のときに低い值をしめした。

\section{IV 考察}

1. 接続管及び切換コックについて

作業能力の評価 ${ }^{199)}$, 作業強度の測定 ${ }^{6) 10)}$, トレ ーニング効果の検討4) 等に, しばしば酸掑素取量
の測定がおこなわれるが，酸素摄取量を測定する ためには，換気量の測定を扣こなわなければなら ない。

われわれは，換気量の測定に，現在一般に使用 されている労研式の採気マスク，ダグラスパッグ を使用しているが，最近，競技選手の呼吸機能を 測定する機会が多くなるにしたがい，従来の採気 マスクでは，選手の作業時換気量を测定すること に困難を感じる例があらわれてきた。その理由 は，作業にともなって盛んになる呼吸運動がマス 
クの呼気口の狭すぎることによって阻害され，選 手の能力が十分に発揮されないということであ る。このことは, 前述のよ 離ランナーの換気量の測定に 2 ロマスクを使用 し，それによって得た值を従来のマスク使用によ る測定値と比較した結果たしかめられた。そこで 本研究では, 従来のマスクの他に， $24 \mathrm{~mm} ， 30$ $\mathrm{mm}, 34 \mathrm{~mm}$ の異る口径の呼気口を有する採気、 スクを製作し，これに前述の 2 ロマスクを加兄 て 5 種類のマスクを準備し，それぞれのマスク使 用時の換気量の比較を試みそれによって作業時换 気量の測定に十分な呼気口の口径を決定しょうと した。

予備実験の段階で，換気運動に影響を与るもの として, マスク呼気口の他に接続管, 三方コッ ク，ダグラスバッグのコックのロ径が考えられる が，これらの採気器具についても若干の検討を加 えた。

接続管の口径の決定のために, $13.5 \mathrm{l}$-Benedict -Roth 型レスピロメーターのマウスピース接続活 栓部と接続ゴム管の部分を改造し，数種の異る内 径の接続管を使用して，それぞれに和ける最大換 気量 (MBC) を測定した。5名の青年男子の被検 者の $\mathrm{MBC}$ は接続管の内径が $18 \mathrm{~mm}$ 以下のとき には，各自の最大值にいたらないが，25mm でほ とんど最大值に到達している。これによって，わ れわれは, 換気量の個人差, 安全性を考虑のう え，接続管の内径を $30 \mathrm{~mm}$ とした。また，三方コ ックの呼気通過口も改造し, ハッッのコックも同 ロ径に作りかえた。

本研究で使用した接続管の内径は，D.B. Dill ${ }^{5)}$ によって報告されている接続管の内径の $40 \mathrm{~mm}$, B. Saltin and P. O. Åstrand ${ }^{8)}$, あるいは N. B. Slonin 等9) の使用している 接続管の内径 $35 \mathrm{~mm}$ よりも小さい。しかし，かれらの使用している呼 気口の直径は, N. B. Slonin 等の場合は不明であ るが, Dill のものが $30 \mathrm{~mm}$, Saltin のものが 28 $\mathrm{mm}$ である。いずれる，マスクの呼父句よりも接 続管の内径が大きくなっている。これは, 生理的 にその径が必要というのではなく，むしろ，呼気 マスクと接続管の接続機構のためにそうなったも のと考えられる。

2. オールアウトタイム, ならびに心拍数, 呼吸数に

\section{つい}

各被㭘者の呼吸循環機能か十分に発挥されるよ 5に選定されたそれぞれの速度のオールアウト走 の時間は， 5 名中 4 名が従来のマスク着用時に短 かかった。このことは, 従来のマスクを使用する ことが，被検者の走行を持続するのに不利な影響 を与えることを示している。

各被㭘者のオールアウト時心拍数はマスクの種 類の影響を5けないよ5であるが，呼吸数の比較 からは，明らかにマスクの口径の大きさが呼吸機 能に影響しているように思われる。

貫井 (Nukui) の例では，従来のマスクを使用 したときに，65回/分の最大呼吸数を示したのに 対し，マスクを使用しないとき，あるいは他のマ スクを使用したときには，95〜100 回という值を 示した。

興味深いことは，体格の大きい被検者のほ5 が, 従来のマスク使用時と他のマスク使用時との 呼吸数の差が大きいという傾向がみられることで ある。扣とらく，呼気口が小さいときには換気量 の増加にしたがい弁の抵抗をうけるため，強い呼 気運動をおこなわなければならず，その結果体格 が大きく換気量の多い被検者ほど呼吸回数が少く なるのではないかと考えられる。

\section{3. 走行中換気量について}

次に走行中換気量の変動から呼気口の大きさの 影響をみると，いずれの被検者でも従来のマスク を使用したとき換気量の少ないことがしめされ た。そしてロ径の大きなマスク使用時の換気量と の差は，走行時間の経過にしたがって大きくなる ことが認められた。このことは，走行初期の換気 量增加が少ない時期には，呼気口の口径の大きさ があまり影響を与えないが，その後換気量が増大 するにしたがって次第に影響が大きくなることを しめするのである。

走行中の換気量の最大值と呼気口の口径との関 係は，採気マスクの呼気口が $24 \mathrm{~mm}$ あれば，ほぼ 最大に近い换気量を測定できるすのと考兄られ る。しかし，5名の被㭘者の5ち体格の大きい 2 名の被検者は, $30 \mathrm{~mm}$ でさらに大きな測定值をし めしたので， $24 \mathrm{~mm}$ の口径で十分とはいえないよ うである。

しかし， $34 \mathrm{~mm}$ の口径の場合でも換気量は内径 
$30 \mathrm{~mm}$ のそれを上回ることは認められなかった。 したがって, 測定の対象が本研究の被㭘者のよ5 に, 換気能力が毎分 $200 l$ を越えない程度であれ ば，30mm の口径で採気をおこなえば，十分であ ると考えられる。

走行中換気量の最大值と $\mathrm{MBC}$ との比率の値を をみると，従来のマスクを使用したときの走行中 最大換気量は， MBC のおよそ $60 \%$ になるが， 呼気口の口径が大きくなるとこの值は，およそ80 \%に達する。

MBC の値に対する，作業中の最大換気量の割 合については, N. Balfour らの報告9) がある，か れらは, $38 \mathrm{~mm}$ の内径の接続管, $35 \mathrm{~mm}$ の内径の 三方コック等を使用 して，50名の 男子鍛練者の 最大酸素摄取量の測定を括こない，その報告の中 で，MBCにたいする走行中最大換気量の割合は 平均 $83 \%$ であったと述へておりこの值は本研究 の值とほぼ等しい。おそらく，呼気口の口径が十 分に広ければ，走行中の最大換気量は $\mathrm{MBC}$ のお よそ $80 \%$ に達すると考えられる。

走行中の呼気の採集に用いられるマスクの呼気 口の口径に言及したものとして, 前述の D.B. Dill の報告5), B. Saltin 等8)の報告がある。Dill は30 $\mathrm{mm}$, Saltin らは $28 \mathrm{~mm}$ の口径の呼気口のマスク を使用している。Saltinは, 競技種目別選手の最 大酸素摂取量の測定に，この口径を用いている。

な技本研究では, 呼気并については, 特別の考 虑をはらわずに従来と同様のゴム製の弁を使用し たが，呼気口の口径を $30 \mathrm{~mm}$ 以上にした場合に は, 并の取付けに留意しなければ弁の開閉が十分 そ打こなわれないといらことが認められ、このこ とは特に換気量の少ない安静時の測定において顕 著であった。このことは, 呼気口の桩大とともに 弁の構造にも考慮する必要性が生ずることをしめ すものである。

\section{4. 酸素摄取率について}

呼気口の内径の大きさの呼吸に及ぼす影響は, 単に呼吸数, 換気量だけでなく, 酸素摄取率にも 現われる。酸素摄取率の走行中の変動を呼気口の 内径別に比較すると, 走行中は従来のマスク使用 時に比較的高い値をしめすものと，逆に低い値を しめすあのがある。
しかし,オールアウト時にしめす摂取率は, 各 被検者とも，それぞれ従来のマスク使用時より も他のマスク使用時のほうがより低かった。酸素 撕取率を肺における呼吸効率の指標》考えるな らば,これらの結果の意味することは, 従来のマ スクを使用して走行を持続する時, 呼吸効率が走 行維持不能の状態に低下する以前に何らかの原因 によってオールアウト状態が招来されるというこ とになろう。その原因を明らかにするためには, さらに検討を加えなければならないが，呼気に含 まれる炭酸ガスの割合も, 従来のマスク使用時よ り口径の大きいマスク使用時に低い值をしめし てオールアウトにいたることから，マスクの口径 が単に呼吸数, 換気量のみに影響を与えるだけで なく，呼吸の効率にも作用していることが考えら れよ5。

\section{5. 酸素摄取量について}

最大酸素积取量は, 有酸素的作業能力の有力な 指標 ${ }^{1)}$ とされているので, この值が従来の換気マ スク使用時に小さいとい5ことは, 作業能力の評 価の5えでマスクの使用に注意を払わなければな らないことをしめしている。酸素拄取量の値から みても，30mm の口径が望ましいと考えられる。

以上の結果から, 従来用いられている採気マス クは, 激しい作業の際の換気量測定には不十分で あることが明らかになった。ここで問題となるこ とは換気量がどの程度增大したときにマスクの影 響が生じるかということである。この点を明らか にするために, 同一被検者が 2 種の異る口径の呼 気口を有すマスクを装着して，それぞれ同一の速 度でオールアウト走を抗こなったときに，それぞ れの走行時の対応する時間における換気量を比較 し図 16 を得た。

図 16 にしめすよ5に $30 \mathrm{~mm}$ 口径のマスク使用 時の換気量と $19 \mathrm{~mm}$ 口径のマスク使用時の換気 量との差は, 換気量の增大に従って大きくなる。 5 名の被検者の測定結果から両方のマスクのそれ ぞれの值が一致する点を推測すると，およそ50l 分の值になる。したがって, $50 \mathrm{l} /$ 分以上の換気量 の要求される作業での換気量の測定に, 従来のマ スクを使用することは妥当でないと考えられる。 


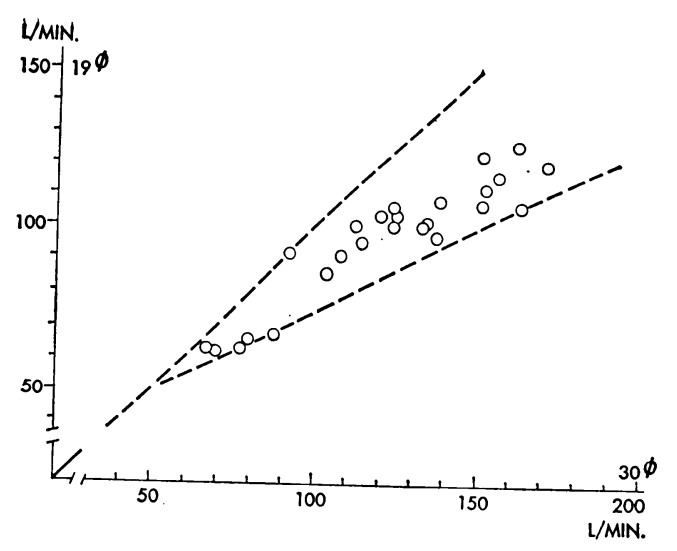

Fig. 16 Relation between $\dot{V}_{E}$. and Diameter of Resp. Valve

\section{$\mathrm{V}$ 結論}

1.作業時呼気の採集に必要な採気マスク呼気 口の口径について検討した。

2. 内径 $24 \mathrm{~mm}, 30 \mathrm{~mm}, 34 \mathrm{~mm}$ の呼気口を有 する採気マスクならびに内径 $19 \mathrm{~mm}$ の呼気口を 2 個有する採気マスクを製作した。

3. 接続管, コック類についても若干の検討を 加光, 内径 $30 \mathrm{~mm}$ に改造し実験に使用した。

4. 5名の青年男子被検者にトレッドミルオー ルアウト走を扣こなわせ, マスク別に換気量, 酸 素摄取量, 炭酸ガス排出量, 呼吸数, 心拍数の測 定を扣こない，これらの値と呼気口の口径との関 係を比較検討した。

5. これらの比較検討により, 従来の採気マス ク（呼気口内径 $19 \mathrm{~mm}$ ) を使用して毎分 $50 l$ 以上 の換気量をともな5作業時の呼気の採集を括こな うことは，測定法として不十分であることがわか った。

6. 毎分 $50 l$ 以上の換気量をともな 5 作業時呼 気の採集には呼気口の内径は $30 \mathrm{~mm}$ は必要であ ると考えられる。また内径 $30 \mathrm{~mm}$ の呼気口を有 するマスクでは毎分約 $200 l$ の換気量まで支障な
く測定可能であると考えられる。

\section{文献}

1) Åstrand, I. (1960) : Aerobic work capacity in men and women with special reference to age. Acta Physiol. Scand. 49; 45-60.

2) Åstrand, P. O., and B. Saltin (1961) : Oxygen uptake during the first minutes of heavy muscular exercise. J. Appl. Physiol 16. (6); 971-976.

3) Åstrand, P. O., and B. Saltin. (1961) : Maxim. al oxygen uptake and heart rate in various types of muscular activity. J. Appl. Physiol. 16(6); 977-981.

4) Cureton, T. K. and E. E. Phillips. (1964): Physical fitness change in middle-aged men attributable to equal eight-week periods of training, non training and re-training. J. Sports Med. 4-2, 87-93.

5) Dill, D. B. (1966) : Assesment of work performance. J. Sport Med. 6(1), 3-8.

6) Furusawa, K. (1952) : Relative metabolic rate of work-R. M. R. Part I. Its definition and introductory remarks. 1, 1-9.

7) 猪飼道夫, 江橋慎四郎, 加賀谷熙彦, 他 (1965)： トレッドミル法による青少年の連動処方に関す る研究, 第 2 報, 体育学研究, 8, 3-4, 61-71.

8) Saltin, Bengt and P-O. Åstrand. (1967) : Maximal oxygen uptake in athletes. J. Appl. Physiol. 23(3); 358.

9) Slonim, N. Balfour, David G. Gillespie and William H. Harold. (1957) : Peak oxygen uptake of healthy young men as determined by a treadmill method. J. Appl. Physiol. 10(3) : 401-404.

10）山岡誠一他 (1954)：ラクビー試合のエネルギ 一需要量と疲労について. 体育学研究 7, 425429. 